\title{
Suomalaisten yliopistojen tutkijanuraa koskevat tasa-arvotoimet pohjoismaisessa vertailussa
}

\section{Tiivistelmä}

Vaikka naiset ja miehet ovat suorittaneet suomalaisissa yliopistoissa tohtorintutkintoja jo pitkään saman verran, naiset ovat edelleen vähemmistö ylimmissä akateemisissa positioissa, kuten professuureissa. Analysoin artikkelissa, mitä institutionaalisia tasa-arvotoimia yliopistot ovat hyödyntäneet edistääkseen sukupuolten tasa-arvoa tutkijanuralla. Tämän lisäksi tutkin tasa-arvon edistämisen haasteita. Hyödynnän tarkastelussa analyyttista kategorisointia, joka jakaa yliopistojen henkilöstöpoliittiset tasa-arvotoimet neljään luokkaan. Vertaan analyysissa suomalaisten yliopistojen aikavälillä 2000-2018 hyödyntämiä tasa-arvotoimia ruotsalaisten ja norjalaisten yliopistojen vastaaviin toimiin. Tutkimuksen kyselymuotoinen aineisto on kerätty haastatteluin yliopistoista; päävastaajina olivat henkilöstöpalveluiden edustajat. Tulosten mukaan suomalaisissa yliopistoissa on käytetty tasa-arvotoimia keskimäärin vähemmän kuin Ruotsissa ja Norjassa. Suomalaisten yliopistojen yleisimpiä tasa-arvotoimia ovat tasa-arvo- ja yhdenvertaisuuskomiteat, menettelyprosessit häirinnästä ilmoittamiseksi sekä tasa-arvo- ja yhdenvertaisuuskoulutus. Radikaalimpia ja poliittisesti kiistanalaisempia tasa-arvotoimia, kuten positiivista erityiskohtelua rekrytoinnissa tai pelkästään naistutkijoille kohdennettuja toimia, ei ole hyödynnetty juuri lainkaan. Analyysin mukaan sukupuolineutraali näkemys sukupuolten tasa-arvosta kaventaa suomalaisten yliopistojen keinovalikoimaa edistettäessä naisten tutkijanuria. 


\section{Johdanto}

Naiset ja miehet ovat suorittaneet suomalaisissa yliopistoissa suunnilleen saman verran tohtorintutkintoja jo vuodesta 2005 lähtien. Naisilla vaikuttaa kuitenkin edelleen olevan vaikeuksia edetä tutkijanuralla. Naisten osuus korkeimmissa akateemisissa positioissa on kasvanut hitaasti ja on edelleen matala - 32 prosenttia vuonna 2020 (Vipunen tietokanta 2021). Yliopistojen ja tieteenalojen väliset erot ovat suuria. Sukupuoli onkin edelleen tärkeä muuttuja tutkittaessa ja kehitettäessä akateemisia uria. ${ }^{1}$

Yliopistoilla on työnantajina lakisääteinen velvollisuus edistää sukupuolten tasaarvoa sekä luoda naisille ja miehille yhtäläiset mahdollisuudet uralla etenemiseen. Tanhuan (2020) opetus- ja kulttuuriministeriölle laatima raportti kuitenkin osoittaa, että tasa-arvo- ja yhdenvertaisuussuunnitelmien perusteella tasa-arvon ja yhdenvertaisuuden edistämistoimet ovat useissa yliopistoissa puutteellisia, eivätkä suunnitelmat täytä kaikilta osin tasa-arvolain vähimmäisvaatimuksia.

Jatkan tässä artikkelissa keskustelua samasta teemasta. Pohjoismaisissa hyvinvointivaltioissa on harjoitettu pitkään niin sanottua naisystävällistä politiikkaa, ja sukupuolten tasa-arvon edistäminen tutkimussektorilla on ollut näissä maissa kestoaihe. Täydennän yliopistojen ja koulutuslaitosten tasa-arvotyöstä tehtyä aiempaa tutkimusta (mm. Brunila 2009; Husu 2001; Kantola 2005) tarkastelemalla, millä konkreettisilla toimilla suomalaiset yliopisto-organisaatiot ovat 2000-luvulta lähtien edistäneet sukupuolten tasa-arvoa tutkijanuralla. Tarkastelen yliopistojen tasa-arvotoimia tasa-arvon eri ulottuvuuksia erittelevällä kategorisoinnilla. Hyödynnän kategorisoinnissa aiempaa organisaatioiden tasa-arvo- ja yhdenvertaisuuspolitiikkaa ja -työtä käsittelevää tutkimusta (mm. Fagenson 1990; Kalev ym. 2006; Timmers ym. 2010). Erilaiset tasa-arvotoimet nojautuvat erilaisiin oletuksiin tasa-arvon tiellä olevista keskeisistä esteistä ja strategioista, joiden oletetaan muuttavan tilannetta (Kalev ym. 2006; Nielsen 2017; Timmers ym. 2010).

Tutkin, miten paljon ja minkälaisia institutionaalisia tutkijanuraa koskevia tasa-arvotoimia suomalaiset yliopistot ovat hyödyntäneet aikavälillä 2000-2018. Tämän lisäksi tutkimus syventyy tasa-arvon edistämisen haasteisiin: erittelen

1 Tässä artikkelissa keskitytään kaksijakoiseen sukupuolikäsitykseen naisista ja miehistä, eikä siinä ole tutkittu sukupuolen tai seksuaalisuuden moninaisuutta. 
argumentteja, joilla tutkimukseen osallistuneet vastaajat perustelivat sitä, että yliopistot eivät olleet hyödyntäneet enempää tai tietyn tyyppisiä tasa-arvotoimia.

Tutkimuksen kohteena olivat yliopistojen viralliset koko organisaation kattavat tasa-arvopolitiikat. Siten sen ulkopuolelle jäivät esimerkiksi vain joihinkin tiedekuntiin rajautuneet toimet tai ruohonjuuritason toiminta. Hyödynnän analyysissa kyselymuotoista tutkimusaineistoa, joka on kerätty haastatteluin suomalaisista, ruotsalaisista ja norjalaisista yliopistoista osana pohjoismaista NORDICORE-huippuyksikköä. Korostaakseni kansallisia erityispiirteitä vertaan suomalaisten yliopistojen hyödyntämiä tasa-arvotoimia ruotsalaisten ja norjalaisten yliopistojen vastaaviin toimiin. Pohjoismainen vertailuasetelma on mielekäs, koska maita yhdistää muun muassa samantyyppinen tasa-arvolainsäädäntö (Borchorst ym. 2012). Maat eivät kuitenkaan muodosta yhtenäistä kokonaisuutta, vaan niiden politiikkapainotuksissa on eroavaisuuksia. Vertailevan analyysin lisäksi tarkastelen yliopistojen henkilöstöpoliittisia linjauksia kahdesta kansallisesta erityiskysymyksestä: määräaikaisten työsuhteiden pidentäminen perhevapaan vuoksi ja kutsuprofessuurien (laajamittainen) käyttö.

\section{Tasa-arvotoimien kategorisointi}

Tarkastelen artikkelissani yliopisto-organisaatioita sukupuolten tasa-arvon edistäjinä. Organisaatioiden hyödyntämät tasa-arvotoimet voidaan jakaa eri kategorioihin sen mukaan, minkälaisiin oletuksiin tasa-arvosta, tasa-arvon tiellä olevista esteistä ja toimivista strategioista ne nojaavat (Dobbin ym. 2015; Fagenson 1990; Kalev ym. 2006; Timmers ym. 2010). Hyödynnän artikkelissa tutkimusprojektissamme kehittämäämme analyyttista kategorisointia, joka jakaa yliopistojen henkilöstöpoliittiset tasa-arvotoimet neljään luokkaan.

Naisille kohdennetut toimenpiteet pyrkivät korjaamaan naisten "puutteita", jotta he etenisivät paremmin olemassa olevissa akateemisissa urarakenteissa. Taustalla on havainto naisten ja miesten välisistä, osin tyttöjen ja poikien erilaisten sosialisaatioprosessien tuloksena syntyneistä eroista heidän ominaisuuksissaan, asenteissaan ja käyttäytymisessään (Fagenson 1990). Esimerkiksi mielikuvaan menestyvästä johtajasta liitetään tutkimusten mukaan usein maskuliinisiksi miellettyjä piirteitä, kuten kilpailuhenkisyys ja itsevarmuus. Lund ja Tienari (2019) kuvaavat 
akateemisen työnteon perustuvan yhä enemmän yksilölliseen kilpailuun. Kilpailuasetelma velvoittaa tutkijat sukupuolesta riippumatta omaksumaan maskuliinisen suorituskeskeisen työasenteen, joka tähtää tuottavuuteen etenkin julkaisutoiminnassa (vrt. Parsons \& Priola 2013). Opetukseen painottumista, jota on kuvattu naistapaisen akateemisen työn muotona, ei vastaavasti arvosteta uralla etenemisessä (Jauhiainen 2011). Tutkimuksen mukaan yksilöihin liitetyt, maskuliinisiksi mielletyt ominaisuudet, kuten kilpailuhenkisyys, vaikuttavat myönteisesti akateemisiin rekrytointipäätöksiin, minkä lisäksi sukupuolittuneet verkostot vaikuttavat akateemisella uralla etenemiseen (van den Brink \& Benschop 2011). Naisille kohdennetut tasa-arvotoimet pyrkivät joko korjaamaan naisiin liitettyjä "puutteita" (esim. vähäisempi kilpailuhenkisyys) tai kohentamaan naisten miehiä heikompia olosuhteita (esim. verkostojen puute) interventiostrategioilla. Tällaisiin tasa-arvotoimiin lukeutuvat esimerkiksi naisille suunnatut urakoulutukset ja mentorointi.

Käyttäytymismuutokseen tähtäävät toimenpiteet korostavat tarvetta muuttaa organisaatiokulttuuriin liittyviä arvoja ja käytäntöjä. Yliopistot ovat osa laajempaa yhteiskuntaa, jota värittävät kulttuuriset arvot sekä yhteiskunnalliset ja rakenteelliset käytännöt ja stereotypiat miesten ja naisten rooleista (Fagenson 1990). Tähän analyyttiseen kategoriaan kuuluvat toimet pyrkivät korjaamaan henkilöstön ja avainhenkilöiden, kuten akateemisten johtajien ja rekrytointikomiteoiden jäsenten, sukupuoleen ja yhdenvertaisuuteen liittyviä ajatusvinoumia ja stereotypioita, jotka voivat uusintaa epätasa-arvon rakenteita (Kalev ym. 2006). Kategoriaan sisältyvien tasa-arvotoimien, kuten tasa-arvo- ja yhdenvertaisuuskoulutuksen, tavoitteena on vaikuttaa akateemisen henkilöstön sekä rekrytoinneista ja ylentämisprosesseista vastaavien portinvartijoiden käyttäytymiseen.

Organisatorista vastuuta korostavat toimenpiteet keskittyvät tasa-arvotyön vastuusuhteiden määrittelyyn. Organisatoristen vastuusuhteiden määrittely on edellytys sille, että tasa-arvo- ja yhdenvertaisuusohjelmat ovat tehokkaita (Kalev ym. 2006). Organisatorista vastuuta korostavat rakenteet ja toimet, kuten tasa-arvo- ja yhdenvertaisuuskomiteat, painottavat vastuiden määrittelyn tärkeyttä paitsi organisatoristen tasa-arvotavoitteiden asetannassa myös niiden seurannassa ja päivittämisessä.

Positiivisen erityiskohtelun toimenpiteet tunnistavat naisten ja miesten erilaisen aseman työmarkkinoilla ja painottavat rakenteellisia tekijöitä tasa-arvon toteutumisen esteinä. Sen sijaan että rekrytointi ja eteneminen akateemisella uralla nähtäisiin sukupuolineutraaleina, tiettyihin meriitteihin pohjautuvina objektiivisina 
järjestelminä, erityisesti feministiset tutkijat ovat huomauttaneet, että rekrytointija uralla etenemisen järjestelmät voivat pikemminkin ylläpitää ja tuottaa epätasaarvon rakenteita (mm. Mählck ym. 2020; Nielsen 2016; Powell ym. 2018; van den Brink \& Benschop 2011). Positiivinen erityiskohtelu haastaa organisaatioissa vallitsevia, erityisesti organisaation jäseneksi pääsyyn ja uralla etenemisen edellytyksiin liittyviä valtarakenteita ja hierarkioita (Fagenson 1990; Kanter 1977; Timmers ym. 2010). Näkökulma korostaakin erityistoimenpiteiden tarvetta, jotta naisten asema ja lähtöolosuhteet yliopistossa tai tietyillä tieteenaloilla paranisivat. Toimiin lukeutuvat muun muassa positioiden ja rahoituksen korvamerkintä.

Naisille kohdennetut toimenpiteet sekä positiivista erityiskohtelua edustavat tasa-arvotoimet kohdistuvat aliedustetun ryhmän edustajiin. Ajatuksena on, että tarvitaan pidemmälle meneviä, naisia suosivia interventiostrategioita, jotta sukupuolten tasa-arvo toteutuisi esimerkiksi ylemmillä uraportailla. Käyttäytymismuutokseen tähtäävät toimet sekä organisatorista vastuuta korostavat toimet voivat puolestaan olla sisällöltään sukupuolineutraaleja. Erottelu istuu suomalaiseen työelämäkontekstiin, jossa tasa-arvokeskustelua hallitsee sukupuolineutraalius ja työntekijöiden yhdenmukainen kohtelu (Korvajärvi 2011; Ylöstalo 2012). Erittelenkin analyysissa paitsi sitä, minkä tyyppisiä tasa-arvotoimia yliopistoissa on hyödynnetty, myös haastatteluissa esiin nousseita argumentteja, jotka auttavat ymmärtämään, miksi tietynlaiset toimet korostuvat suomalaisissa yliopistoissa toisten sijaan.

\section{Akateeminen työ sukupuolinäkökulmasta: pohjoismainen ja suomalainen tarkastelu}

\section{Kansalliset tasa-arvotyötä tukevat rakenteet}

Pohjoismaat on eurooppalaisessa vertailussa tunnistettu tutkimussektorin edelläkävijöiksi tasa-arvon edistäjinä (Lipinsky 2013). Esimerkiksi sukupuolten välisen palkkatasa-arvon seuranta ja edistäminen sekä tasa-arvo- ja yhdenvertaisuussuunnitelmat ovat osa pohjoismaista tasa-arvolainsäädäntöä. Pohjoismaat eivät yhtäläisyyksistään huolimatta kuitenkaan muodosta yhtenäistä kokonaisuutta, vaan tutkimussektoria koskevissa politiikkapainotuksissa on eroja niin kansallisella kuin yliopistotasolla (ks. Nielsen 2014; 2017). Esimerkiksi 1990-luvulla Ruotsissa hyö- 
dynnettiin kansallisen politiikka-aloitteen myötä sukupuolikiintiöitä akateemisissa rekrytoinneissa (ns. Tham-professuurit) (Jordansson 1999) ja Norjassa korvamerkittiin positioita aliedustetun sukupuolen edustajille (Brandt ym. 2002). Vaikka suomalainen lainsäädäntö mahdollistaa positiivisen erityiskohtelun tietyin reunaehdoin, tätä mahdollisuutta ei ole yliopistoissa hyödynnetty (Husu 2001, 86-87), eikä vastaavaa kansallisen tason politiikkaa ole Suomessa ollut.

Valtioneuvoston selonteon väliraportti naisten ja miesten välisestä tasa-arvosta nostaa naisten tutkijanuran edistämisen yhdeksi tavoitteeksi (VN 2017, 27-29). Raportissa huomautetaan naisten hitaasta etenemisestä korkeimpiin opetus- ja tutkimustehtäviin. Siinä perätään sukupuolinäkökulman systemaattista sisällyttämistä tutkijanurien kehittämistä koskevaan työhön sekä tutkijanuramallien ja rahoituskäytäntöjen arviointiin. Yhtenä toimenpiteenä Marinin hallitus (2019-) teettää selvityshankkeen tasa-arvon ja yhdenvertaisuuden toteutumisesta tutkimus-, kehitys- ja innovaatiotoiminnassa (Sosiaali- ja terveysministeriö 2020, 63).

Tasa-arvotyötä yliopistoissa vaikeuttaa Brunilan (2009) mukaan se, että tasaarvokysymykset on pidetty Suomessa tyypillisesti erillään koulutus- ja tiedepolitiikasta. Tasa-arvon edistäminen ei ole ollut yliopistojen strategioiden ytimessä, eikä sukupuolinäkökulman valtavirtaistaminen opetuksessa ja tutkimuksessa ole toteutunut. Tanhuan (2020) opetus- ja kulttuuriministeriölle laatima raportti osoittaa, että yliopistojen tasa-arvo- ja yhdenvertaisuustyö on monelta osin puutteellista. Yliopistojen toimenpiteet tasa-arvon edistämiseksi jäävät usein abstraktille tasolle.

Tasa-arvotyötä suomalaisessa työelämässä on leimannut lyhytjänteinen projektimaisuus, mikä on vaikeuttanut pitkäjänteisten politiikkatavoitteiden saavuttamista (Brunila \& Ylöstalo 2015; Julkunen 2009). Suomalaisella tutkimussektorilla ei ole esimerkiksi ollut kansallista tasa-arvoon keskittyvää komiteaa kuten Norjassa ja Ruotsissa. Sen sijaan Suomessa on toiminut eri vuosikymmeninä vaihtuvia työryhmiä, jotka ovat pyrkineet pureutumaan naisten asemaan tutkimussektorilla (esim. Opetusministeriö 1982; 2006; Suomen Akatemia 1997). Työryhmät ovat antaneet suosituksia, mutta on epäselvää, miten suositusten toimeenpanoa on seurattu.

Toiseksi yliopistolait Ruotsissa ja Norjassa sisältävät tasa-arvoon liittyviä määräyksiä (Nielsen 2014), kun taas Suomessa voimassa oleva yliopistolaki on sukupuolineutraali. Yliopistolain valmistelussa ja tutkijanuria koskevissa arvioinneissa ei ole aina riittävästi huomioitu sukupuolinäkökulmaa (HE 7/2009 uudeksi yliopistolaiksi, 45-46; Niemi 2009; Tasa-arvoasiain neuvottelukunta 2011, 98-99). Kaik- 
kinensa Suomessa vallinnut tehokkuutta ja kilpailua korostava yliopistopolitiikka (Rinne ym. 2012) ei liene ollut otollinen sosiaalisten tavoitteiden edistämiselle yliopistosektorilla.

Kansallisen tutkimussektorin kattavan tasa-arvokomitean puuttuminen ja sukupuolineutraali lainsäädäntö kuvastavat Suomen pohjoismaisia naapurimaitamme kapeampia tasa-arvotyötä tukevia kansallisia rakenteita. Eroavaisuudet tutkimussektorilla heijastelevat eroja kansallisessa tasa-arvopolitiikassa sekä yleisissä tasa-arvotyötä koskevissa asenteissa ja tietoisuudessa (vrt. Nielsen 2017; Ylöstalo 2012). Esimerkiksi Norjassa on pitkään käytetty interventionaalista tasa-arvopolitiikkaa, josta esimerkkinä on positiivisen erityiskohtelun yleinen käyttö tasa-arvon edistämisessä työelämässä ja yhteiskunnassa 1980-luvulta lähtien (Nielsen 2017; Teigen 2011).

\section{Suomalaisissa yliopistoissa työskentelevä opetus- ja tutkimushenkilöstö sukupuolen mukaan}

Yliopistot ovat Suomessa suuria työnantajia, minkä vuoksi niiden toimia sukupuolten tasa-arvon edistäjinä on perusteltua tarkastella. Syyskuussa vuonna 2019 yliopistoissa työskenteli 31500 henkilöä, joista hieman yli 60 prosenttia kuului opetus- ja tutkimushenkilöstöön. Opetus- ja tutkimushenkilöstöstä 45 prosenttia oli naisia ja 55 prosenttia miehiä. Yliopistokohtaiset sukupuolierot ovat suuria: naisten osuus vaihteli noin 30 prosentista (Aalto-yliopisto) 65 prosenttiin (Lapin yliopisto). (Sivistystyönantajat 2020, 2, 5.)

Akateeminen työ on Suomessa vertikaalisesti segregoitunut sukupuolen mukaan. Naisten osuus on matala erityisesti neljännellä eli korkeimmalla tutkijanuraportaalla, joka sisältää professorit, akatemiaprofessorit ja tutkimusjohtajat. Kuten taulukosta 1 havaitaan, yliopistojen variaatio on suuri. ${ }^{2}$ Naisten osuus oli pienin teknillisesti

2 Taulukko ei sisällä apurahalla työskennelleitä tutkijoita tai tuntiopettajia. Tutkijoiden työskentelystatukset ovat sukupuolittuneita: enemmistö apurahalla työskentelevistä tutkijoista oli vuonna 2015 naisia (Opetus- ja kulttuuriministeriö 2016, 59). On myös huomattava, että neliportainen uramalli ei ole varsinainen uralla etenemisen väline, vaan sen tarkoituksena on ennen kaikkea selkeyttää akateemisen henkilöstön nimikkeistöä sekä toimia tilastoinnin välineenä (Välimaa ym. 2006, 19). 
orientoituneissa yliopistoissa ja suurin henkilöstömääriltään pienissä yliopistoissa, joissa ei ole teknillistä tai luonnontieteellistä painotusta.

Yliopistokohtaiset erot liittyvätkin Suomessa suurelta osin yliopistojen erilaiseen tieteenalapohjaan: tieteenalat ovat horisontaalisesti segregoituneet sukupuolen mukaan. Suomalaiset työmarkkinat yleisestikin kuuluvat Euroopan segregoituneimpiin (Bettio ym. 2009). Naisten mahdollisuuksia edetä johtotehtäviin kuvaava lasikattoindeksi (Euroopan komissio 2019, 125) saa Suomessa korkeimman arvon teknillisesti orientoituneissa yliopistoissa. Teknillisissä tieteissä neljännellä uraportaalla suoritetuista henkilötyövuosista vain 10 prosenttia ja luonnontieteissä 15 prosenttia oli vuonna 2019 naisten tekemiä, kun humanistissa tieteissä vastaava osuus oli 50 prosenttia (Vipunen tietokanta 2021). Koska yliopistojen sukupuolijakaumat ovat erilaisia, on mielenkiintoista tarkastella, onko yliopistojen tasa-arvotyön aktiivisuudessa ja hyödynnetyissä tasa-arvotoimissa eroja.

\section{Taulukko 1. Naisten prosentuaalinen osuus yliopistoittain tutkijanuratasoilla}

\section{I-IV vuonna 2018}

\begin{tabular}{lcccc}
\hline Yliopistot & $\begin{array}{c}\text { Tutkijanura- } \\
\text { taso I* }\end{array}$ & $\begin{array}{c}\text { Tutkijanura- } \\
\text { taso II }\end{array}$ & $\begin{array}{c}\text { Tutkijanura- } \\
\text { taso III }\end{array}$ & $\begin{array}{c}\text { Tutkijanura- } \\
\text { taso IV }\end{array}$ \\
\hline Aalto-yliopisto & $30,9(914)$ & $30,0(576)$ & $30,2(442)$ & $15,0(243)$ \\
Helsingin yliopisto & $54,5(1177)$ & $53,4(946)$ & $52,5(1256)$ & $32,5(517)$ \\
Itä-Suomen yliopisto & $50,9(468)$ & $62,1(312)$ & $52,9(458)$ & $33,0(248)$ \\
Jyväskylän yliopisto & $59,6(657)$ & $47,2(248)$ & $48,4(384)$ & $34,7(201)$ \\
Lapin yliopisto & $64,8(141)$ & $64,6(73)$ & $68,6(44)$ & $57,8(46)$ \\
Lappeenrannan-Lahden teknillinen yliopisto & $35,1(238)$ & $40,9(126)$ & $40,2(92)$ & $15,0(74)$ \\
Oulun yliopisto & $42,7(717)$ & $43,6(372)$ & $42,8(310)$ & $30,6(187)$ \\
Tampereen teknillinen yliopisto & $29,1(463)$ & $28,1(297)$ & $22,4(111)$ & $5,6(94)$ \\
Tampereen yliopisto & $66,4(367)$ & $61,3(206)$ & $54,2(326)$ & $40,6(179)$ \\
Turun yliopisto & $55,0(543)$ & $57,5(604)$ & $49,9(408)$ & $37,5(281)$ \\
Vaasan yliopisto & $46,5(78)$ & $50,7(57)$ & $50,6(52)$ & $24,1(51)$ \\
Ábo Akademi & $48,8(145)$ & $57,0(256)$ & $47,2(94)$ & $27,4(85)$ \\
Svenska handelshögskolan & $40,9(29)$ & $62,4(44)$ & $32,1(33)$ & $29,8(30)$ \\
Taideyliopisto & $60,7(32)$ & $60,2(21)$ & $47,5(156)$ & $50,5(55)$ \\
\hline Suluis) & & &
\end{tabular}

* Suluissa ko. yliopiston kokonaishenkilötyövuodet kullakin tutkijanuratasolla.

Lähde: Vipunen tietokanta 2021. 
Valtaosa yliopistojen opetus- ja tutkimushenkilöstöstä työskentelee määräaikaisissa työsuhteissa. Vuonna 2019 määräaikaisten työsuhteiden osuus oli tohtorintutkinnon suorittaneilla 54 prosenttia. Sukupuolierot olivat suurimmat professoritasoisissa tehtävissä: naisista määräaikaisissa tehtävissä työskenteli 28 prosenttia, miehistä 23 prosenttia (Sivistystyönantajat 2020, 6). Eräs määräaikaisuuksiin liittyvä tasa-arvokysymys on, onko yliopistolla politiikkalinjausta työsopimusten jatkamisesta perhevapaiden vuoksi. Jo opetusministeriön asettama työryhmä vuonna 1982 suositteli yliopistoja jatkamaan määräaikaisia työsopimuksia, jotka katkeavat perhevapaiden vuoksi. Aihe on yliopistoissa edelleen ajankohtainen. Esimerkiksi professorien vakinaistamisjärjestelmä (ns. tenure track) sisältää urapolun alkuvaiheessa yleensä määräaikaisia työsuhteita ja ajoittuu työntekijän näkökulmasta usein samaan ajankohtaan mahdollisen lastensaannin kanssa (Pietilä 2019).

Toinen Suomessa toistuvasti esiin nostettu tasa-arvokysymys koskee eri rekrytointitapojen sukupuolivaikutuksia. Bain ja Cummings (2000) painottavat rekrytoinnin avoimuuden ja läpinäkyvyyden tärkeyttä tasa-arvotyössä, koska suljettujen ja epämuodollisten rekrytointikäytäntöjen on todettu suosivan miehiä. Husun tutkimuksen (2001, 78-80) mukaan valtaosa suomalaisiin yliopistoihin professoreiksi kutsutuista oli vuosina 1997-2000 miehiä, kun taas naiset pärjäsivät suhteellisesti paremmin avoimissa hauissa (ks. myös Nielsen 2016). Edelleen vuosina 2010-2014 tehtävään kutsutuista valtaosa, 76 prosenttia, oli miehiä (Välimaa ym. $2016,41)$.

\section{Tutkimusaineisto ja menetelmät}

Hyödynnän tutkimuksessa aineistoa, joka on kerätty osana pohjoismaista NORDICORE-huippuyksikköä. Kyselymuotoinen aineisto kerättiin haastatteluin. Kyselyllä kartoitettiin suomalaisten, ruotsalaisten ja norjalaisten yliopistojen sukupuolten tasa-arvoon ja yhdenvertaisuuteen liittyviä koko organisaation kattavia tasa-arvotoimia sekä niiden ajankohtaa. Koska suomalaisten yliopistojen institutionaalinen autonomia on 2010-luvulla lisääntynyt ja päätöksentekoa on keskitetty ylimmälle johdolle (Pietilä 2018; Rinne ym. 2012), yliopistojen yhteiset politiikat ovat keskeisiä. 
Kysely kattoi laajan joukon (noin 90 kysymystä) tasa-arvoon ja yhdenvertaisuuteen liittyviä toimia, joista valitsin osan tämän artikkelin analyysiin. ${ }^{3}$

Tutkimuksen kohdejoukkona olivat ne organisaatiot Suomessa, Ruotsissa ja Norjassa, joilla oli vuonna 2018 yliopistostatus. Kaikki suomalaiset yliopistot ( $N=14$ ) osallistuivat tutkimukseen. ${ }^{4}$ Norjasta tutkimukseen osallistui yhdeksän yliopistoa ja Ruotsista 14. Toteutimme tutkimushaastattelut syksyn 2018 ja kesän 2020 välisenä aikana joko kasvotusten tai puhelimitse. Haastattelin suomalaisista yliopistoista yhteensä 37 henkilöä. Kooltaan suurista yliopistoista haastattelin tyypillisesti useaa vastaajaa, pienemmistä vain yhtä. Kollegani Ruotsista ja Norjasta toteuttivat omien maidensa haastattelut. Pääosa Suomessa haastatelluista työskenteli yliopistoissa henkilöstö- tai hallintotehtävissä, esimerkiksi henkilöstöjohtajana, hallintojohtajana tai henkilöstöasiantuntijana. Heillä oli asemansa puolesta laajat tiedot yliopistojen henkilöstöpolitiikoista. Osa vastaajista toimi yliopistojen tutkimuspalveluissa tai opetus- ja tutkimustehtävissä.

Kysymykset edustivat binäärimuuttujia, joiden vastausvaihtoehdot olivat "kyllä" ja "ei" (lisäksi vastausvaihtoehtoja olivat "en tiedä" ja "en halua vastata"). Haastatteluissa kysyttiin, onko yliopisto hyödyntänyt tiettyä tasa-arvotoimea 1990-luvun puolivälin jälkeen. Jos vastauksena oli kyllä, kysyimme lisäksi, mistä alkaen mainittu toimenpide oli ollut käytössä ja oliko käyttö sittemmin lopetettu. Mikäli haastateltava ei osannut vastata, kysyimme asiasta toiselta henkilöltä tai pyysimme vastaajaa tarkistamaan tiedon esimerkiksi arkistosta. Rajaudun tässä artikkelissa tasa-arvotoimiin, joita yliopistot ovat käyttäneet vuosina 2000-2018, koska suurin osa toimista ajoittui tälle aikavälille.

Tutkimuksen rajoitteena on, että se ei kerro, missä määrin jotakin politiikkatoimea on yliopistossa tosiasiassa hyödynnetty. Esimerkiksi yliopistojen häirintäilmoitusjärjestelmien olemassaolosta huolimatta seksuaalinen häirintä on yliopistoissa

3 Tutkimusryhmämme hyödynsi kyselylomakkeen muotoilussa professori Alexandra Kalevin ja professori Frank Dobbinin tutkimusryhmän kehittämää lomaketta. Heidän tutkimusryhmänsä on tutkinut Yhdysvalloissa toimivien organisaatioiden yhdenvertaisuuspolitiikkoja. Tutkimusryhmämme muokkasi lomaketta pohjoismaiseen kontekstiin sopivaksi.

4 Aineistossa on mukana entinen Tampereen yliopisto ja entinen Tampereen teknillinen yliopisto, jotka vuonna 2019 muodostivat yhdessä Tampereen ammattikorkeakoulun kanssa uuden Tampereen yliopiston. 
edelleen ongelma (Salmesvuori 2020): tietyn organisatorisen linjauksen olemassaolo ei takaa, että se tunnettaisiin laajasti työyhteisössä tai että sitä aktiivisesti hyödynnettäisiin. Koska tutkimuksen kohteena olivat koko yliopiston kattavat, viralliset tasa-arvotoimet, sen ulkopuolelle rajautuivat myös yksikkökohtainen (ml. tiedekuntakohtainen) toiminta ja ruohonjuuritason aktivismi.

Olen valinnut tämän artikkelin analyysiin muuttujat (19 kpl), jotka kuvaavat edellä esittelemiäni analyyttisia kategorioita. Määrällinen analyysi perustuu toimenpiteiden esiintymisfrekvenssien ja tilastollisten hajontalukujen tarkasteluun sekä graafiseen esitykseen. Hyödynnetyt muuttujat löytyvät artikkelin tulososasta taulukosta 3. Analyysi ei sisällä toimia, jotka seuraavat suoraan lainsäädännöstä (mm. tasa-arvoja yhdenvertaisuussuunnitelmat). Analyysiin valitut toimet edustavat siten yliopistojen itse valitsemia toimia, joilla ne pyrkivät edistämään sukupuolten tasa-arvoa. Lisäksi tarkastelen erikseen yliopistojen linjauksia kahdesta suomalaisessa keskustelussa pitkään esillä olleesta erityiskysymyksestä: määräaikaisten työsuhteiden pidentäminen perhevapaan vuoksi ja kutsumenettelyn käyttö professorien rekrytoinnissa.

Koska tasa-arvotoimien määrä osoittautui suomalaisissa yliopistoissa keskimäärin verrattain pieneksi, erittelen haastatteluissa esiin tulleita perusteluja, miksi yliopistot eivät olleet hyödyntäneet enemmän tai tiettyjä tasa-arvotoimia. Argumentit kontekstualisoivat suomalaisten yliopistojen tasa-arvotyöhön liittyvää problematiikkaa (vrt. Ylöstalo 2013). Haastatteluissa ei kysytty, miksi tietty tasa-arvotoimi oli otettu tai miksi sitä ei ollut otettu käyttöön. Argumentit tasa-arvotoimien vähäisyydelle tulivatkin esiin haastateltavien perustellessa vastauksiaan vapaamuotoisesti. Tunnistetut argumentit perustuvat haastattelumuistiinpanojeni aineistolähtöiseen sisällönanalyysiin (Tuomi \& Sarajärvi 2002). Lisäksi argumenttien tunnistamista ohjasi tietämykseni sukupuolen- ja korkeakoulututkimuksesta.

\section{Tulokset}

\section{Yliopistojen tasa-arvopolitiikat}

Tarkastelen aluksi määrällisesti, mitä toimia suomalaiset yliopistot ovat hyödyntäneet edistääkseen sukupuolten tasa-arvoa tutkijanuralla. Hyödynnän analyysissa tasa-arvon eri ulottuvuuksia erittelevää kategorisointia. Suomalaisten yliopistojen 
tasa-arvotoimien määrä on lisääntynyt aikavälillä 2000-2018. Taulukko 2 sisältää suomalaisten, ruotsalaisten ja norjalaisten yliopistojen tasa-arvotoimien keskiarvot, mediaanit ja keskihajonnat.

Tasa-arvotoimien kokonaismäärä oli suomalaisissa yliopistoissa koko tarkastelujaksolla keskimäärin 3,9 yhtä yliopistoa kohden ja mediaani oli 4 (kun tasa-arvotoimien yhteismäärä oli 19). Keskiarvo ja mediaani olivat pienempiä kuin ruotsalaisissa (keskiarvo 7,4; mediaani 7,5) ja norjalaisissa (keskiarvo 10,8; mediaani 11) yliopistoissa. Keskihajonta oli Suomessa kaikkien tasa-arvotoimien osalta 1,5 (Ruotsissa 3,2 ja Norjassa 4,7). Suurista yliopistokohtaisista eroista huolimatta opetus- ja tutkimushenkilöstön sukupuolijakaumissa (taulukko 1) yliopistojen välillä ei siis ollut merkittäviä aktiivisuuseroja tasa-arvotyössä. Henkilöstömääriltään suuret yliopistot olivat hyödyntäneet keskimäärin enemmän toimia kuin pienet yliopistot.

Pääosa suomalaisten yliopistojen hyödyntämistä tasa-arvotoimista kuuluu organisatorista vastuuta (keskimäärin 2,1 toimea yliopistoa kohden) ja käyttäytymismuutoksia painottaviin kategorioihin (keskimäärin 1,5 toimea). Suurin suomalaisten yliopistojen välinen hajonta liittyy käyttäytymismuutokseen tähtääviin toimiin.

Suurimmat maiden väliset erot ovat naisille kohdennetuissa toimissa sekä positiivisessa erityiskohtelussa. Suomalaiset yliopistot eivät ole hyödyntäneet näitä kategorioita edustavia tasa-arvotoimia juuri lainkaan. Etenkin norjalaisissa yliopistoissa on ollut naisille kohdennettuja toimia sekä positiivista erityiskohtelua. Kummankin kategorian tasa-arvotoimien mediaani on Norjassa neljä (vrt. Suomessa nolla ja Ruotsissa yksi). Positiiviseen erityiskohteluun Norjassa lukeutuvat muun muassa positioiden korvamerkintä ja kutsumenettely professuuriin heikommin edustetun sukupuolen edustajien osuuden kasvattamiseksi. Ruotsalaiset yliopistot ovat hyödyntäneet positiivista erityiskohtelua ja naisille kohdennettuja toimia jonkin verran, mutta vähemmän kuin norjalaiset yliopistot. 
Taulukko 2. Suomalaisten, ruotsalaisten ja norjalaisten yliopistojen tasa-arvotoimien lukumäärät vuosina 2000-2018

\begin{tabular}{lccccccccc}
\hline & \multicolumn{2}{c}{ Suomalaiset yliopistot } & \multicolumn{2}{c}{ Ruotsalaiset yliopistot } & \multicolumn{2}{c}{ Norjalaiset yliopistot } \\
\hline & $\begin{array}{l}\text { keski- } \\
\text { arvo }\end{array}$ & & $\begin{array}{c}\text { keski- } \\
\text { hajonta }\end{array}$ & $\begin{array}{c}\text { keski- } \\
\text { arvo }\end{array}$ & $\begin{array}{c}\text { mediaani } \\
\text { keski- } \\
\text { hajonta }\end{array}$ & $\begin{array}{c}\text { keski- mediaani } \\
\text { arvo }\end{array}$ & $\begin{array}{c}\text { keski- } \\
\text { hajonta }\end{array}$ \\
\hline $\begin{array}{l}\text { Naisille kohdennetut } \\
\text { toimenpiteet }\end{array}$ & 0,1 & 0 & 0,3 & 1,5 & 1 & 1,5 & 2,9 & 4 & 2,3 \\
$\begin{array}{l}\text { Käyttäytymismuutokseen } \\
\text { tähtäävät toimenpiteet }\end{array}$ & 1,5 & 1,5 & 1,4 & 2,1 & 2 & 1,5 & 2,4 & 3 & 1,6 \\
$\begin{array}{l}\text { Organisatorista vastuuta } \\
\text { korostavat toimenpiteet }\end{array}$ & 2,1 & 2 & 0,3 & 2,8 & 3 & 0,6 & 2,8 & 3 & 0,4 \\
$\begin{array}{l}\text { Positiivista erityiskohtelua } \\
\text { edustavat toimenpiteet }\end{array}$ & 0,3 & 0 & 0,5 & 1,1 & 1 & 1,0 & 2,7 & 4 & 1,7 \\
\begin{tabular}{l} 
Kaikki toimenpiteet \\
\hline
\end{tabular} & $\mathbf{3 , 9}$ & $\mathbf{4}$ & $\mathbf{1 , 5}$ & $\mathbf{7 , 4}$ & $\mathbf{7 , 5}$ & $\mathbf{3 , 2}$ & $\mathbf{1 0 , 8}$ & $\mathbf{1 1}$ & $\mathbf{4 , 7}$ \\
\hline
\end{tabular}

Taulukko 3 sisältää yksityiskohtaisemmat tiedot suomalaisten yliopistojen hyödyntämistä tasa-arvotoimista. Yliopistot on taulukossa järjestetty siten, että vasemmalla sijaitsevat ne yliopistot, joissa on ollut eniten tasa-arvotoimia.

Taulukosta ilmenee, että tasa-arvo- ja yhdenvertaisuuskomiteat sekä menettelyprosessit häirinnästä ilmoittamiseksi muodostavat suomalaisten yliopistojen tasa-arvotyön organisatorisen ytimen. Ne ovat osa institutionaalisia rakenteita kaikissa yliopistoissa. Hyödynnetyt käyttäytymismuutokseen tähtäävät toimet puolestaan sisältävät pääasiassa joko akateemiselle henkilöstölle tai johdolle tarjottavaa (vapaaehtoista) tasa-arvo- ja yhdenvertaisuuskoulutusta. Noin puolet yliopistoista on tarjonnut tällaista koulutusta. Sen sijaan vastaavan koulutuksen tarjoaminen rekrytointi- tai ylentämisistä vastaaville komiteoille sekä ohjeistus sukupuoleen liittyvistä ennakkoasenteista ja stereotypioista ovat harvinaisia. Ainoa positiivista erityiskohtelua edustava hieman yleisemmin käytössä ollut toimi on proaktiivisuus rekrytoinnissa, jotta heikommin edustetun sukupuolen edustajien osuus henkilöstöstä kasvaisi. Tätä on hyödyntänyt neljä yliopistoa. Käytännössä proaktiiviset toimet ovat tarkoittaneet esimerkiksi kirjausta tasa-arvo- ja yhdenvertaisuussuunnitelmassa, että julistettaessa positioita auki naisia kannustetaan hakemaan niitä. Vastaajien mukaan oli kuitenkin epäselvää, kuinka paljon proaktiivisia toimia oli tosiasiassa käytetty. 


\section{Taulukko 3. Suomalaisten yliopistojen tasa-arvotoimet vuosina 2000-2018}

\section{Naisille kohdennetut toimenpiteet}

Rahoitus naisille, jotta he täyttäisivät uralla etenemisen vaatimukset

Tutkimusvapaa naisille miehiä lyhyemmässä ajassa

Mentorointiohjelma naistutkijoille

Uralla etenemiseen liittyvä koulutus naistutkijoille

Verkostoitumistilaisuudet johtavassa asemassa oleville naistutkijoille

Rahoitus naisille johtamisohjelmiin osallistumiseksi

Summa

Tasa-arvo- ja yhdenvertaisuuskoulutus akateemiselle henkilöstölle

Tasa-arvo- ja yhdenvertaisuuskoulutus johdolle

Tasa-arvo- ja yhdenvertaisuuskoulutus rekrytointi- ja ylentämisistä vastaaville komiteoille Koulutus seksuaalisesta häirinnästä akateemiselle henkilöstölle

Ohjeet sukupuoleen liittyvistä ennakkoasenteista rekrytointikomiteoille

Kokemus tasa-arvotyöstä kvalifikaatio laitosjohtajana työskentelemiseksi

Summa

\section{Organisatorista vastuuta korostavat toimenpiteet}

Osasto tai kokoaikainen henkilö vastuussa tasa-arvon ja yhdenvertaisuuden edistämisestä Pysyvä tasa-arvo- ja yhdenvertaisuuskomitea tai vastaava

Menettelyprosessi häirinnästä/seksuaalisesta häirinnästä ilmoittamiseksi

Summa

\section{Positiivinen erityiskohtelu}

Proaktiiviset toimet rekrytoinnissa

Kutsumenettely professuuriin heikommin edustetun sukupuolen osuuden kasvattamiseksi Korvamerkityt varat tai positiot heikommin edustetun sukupuolen rekrytoimiseksi

Rahalliset kannustimet naistutkijoiden palkkaamiseksi

Summa

\section{Kaikki toimenpiteet (yht.)}

\% kaikista toimenpiteistä (yht. 19)

\section{Käyttäytymismuutokseen tähtäävät toimenpiteet}
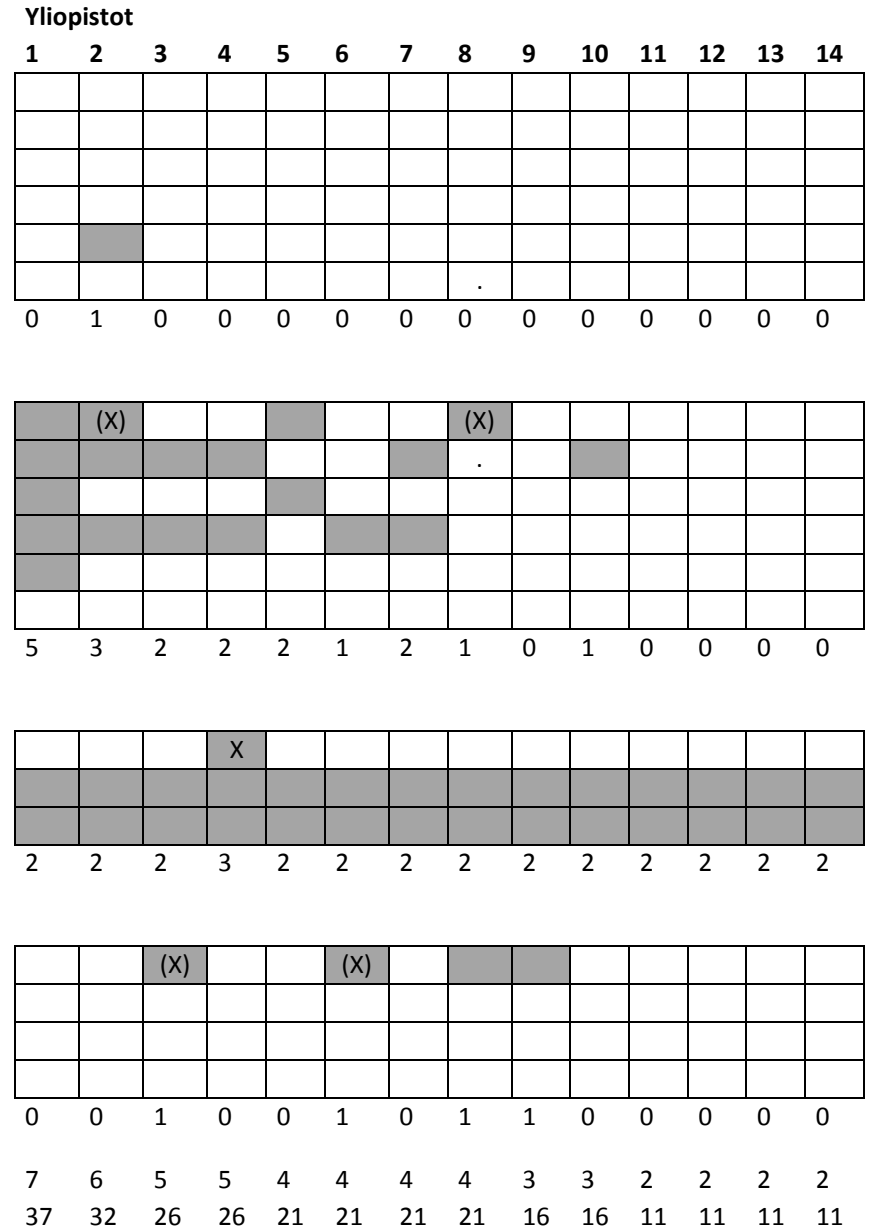

Huom. Harmaa väri tarkoittaa, että toimi oli käytössä v. 2018. X tarkoittaa, että toimi on ollut käytössä, mutta se on lopetettu. (X) tarkoittaa, että toimi on ollut käytössä, mutta ei ole tietoa, oliko se käytössä v. 2018. Piste (.) tarkoittaa puuttuvaa tietoa. 
Tarkastelen vielä, minkälaisia linjauksia yliopistoilla on ollut määräaikaisten työsuhteiden jatkamisesta perhevapaiden vuoksi sekä kutsumenettelyn käytöstä professorirekrytoinnissa.

Kysyimme haastatteluissa, oliko yliopisto tehnyt linjausta määräaikaisten tenure track - työsuhteiden jatkamisesta. ${ }^{5}$ Kymmenessä suomalaisessa yliopistossa ( $71 \%$ ) oli naistutkijoita koskeva linjaus, että määräaikaisuutta jatketaan perhevapaan vuoksi. Näistä neljässä yliopistossa pidennys oli automaattinen, kun taas kuudessa yliopistossa päätös edellytti neuvottelua työnantajan kanssa. Vastaava linjaus koski toista vanhempaa eli isää tai lapsen toista äitiä seitsemässä yliopistossa (50\%). Näistä kolmessa yliopistossa pidennys oli työntekijän oikeus ilman erillistä neuvottelua. Yksikään yliopisto ei ollut haastatteluhetkellä ohjeistanut ylentämisistä päättäviä tahoja siitä, miten perhevapaat ja niiden aiheuttamat ns. tenure-kellon pidennykset tulisi ottaa arvioinneissa huomioon (kahden yliopiston vastaajat eivät tienneet, oliko yliopisto tehnyt tällaista linjausta).

Professorin tehtävä tulee voimassa olevan yliopistolain (2009/558) mukaan asettaa julkisesti haettavaksi, kun henkilö rekrytoidaan pysyvään työsuhteeseen. Laki mahdollistaa tehtävän täytön ilman avointa hakua, "kun tehtävään voidaan kutsua ansioitunut henkilö tai tehtävään valitaan määräajaksi". Kahdessa yliopistossa hyödynnettiin vuonna 2018 laajamittaisesti kutsumenettelyä professuuriin (vähintään $40 \%$ professorirekrytoinneista), ja yhden yliopiston vastaajan mukaan kutsumenettelyn käyttö oli ollut aiemmin laajaa.

\section{Argumentit tasa-arvotoimien vähäisyydelle}

Erittelen seuraavaksi argumentteja, jotka tulivat esiin suomalaissa yliopistoissa tehdyissä haastatteluissa perusteluina sille, että yliopistot eivät olleet hyödyntäneet enemmän tai tiettyjä tasa-arvotoimia. Tuloksia tulkittaessa on huomattava, että vastaukset heijastavat yliopistojen hallintotehtävissä työskentelevien näkökulmia. Haastatteluaineistosta on poimittavissa etenkin viisi perustelua, jotka linkittyvät monelta osin yhteen.

5 Muotoilimme kysymyksen näin, koska määräaikaiset apulaisprofessuurit ovat tyypillisesti yliopistojen budjettirahoitteisia positioita, eikä niiden tulisi siten olla riippuvaisia ulkopuolisesta rahoituksesta ja rahoitukseen liittyvistä aikatauluista. 
Ensimmäinen perustelu toimenpiteiden vähäisyydelle nojaa ajatukseen, että sukupuolten tasa-arvo tutkijanuralla ei ole yliopistoissa varsinainen ongelma. Tällöin viitattiin usein kyseisen yliopiston verrattain tasaiseen opetus- ja tutkimushenkilöstön sukupuolijakaumaan, mutta näkemys tuli laajemminkin esiin. Ongelmia nähtiin enemmänkin opiskelijoiden hakeutumisessa tietyille, sukupuolen mukaan segreroituneille koulutuspoluille, ei tutkijoiden uralla etenemisen sukupuolittuneisuudessa. Hollin (2002) mukaan usko jo saavutettuun tasa-arvoon on suomalaisessa työelämässä yleinen. Lähtökohtana tasa-arvotyölle se on hankala, koska tasa-arvo-ongelmia ei tällöin tunnisteta (Ylöstalo 2012).

Toinen, ensimmäistä argumenttia lähellä oleva perustelu lähestyy akateemista uraa sukupuolineutraalina järjestelmänä, johon tasa-arvoajattelu ei lähtökohtaisesti sovi, koska objektiiviset meriitit, "pätevyys", ratkaisee uralla etenemisen (vrt. Kantola 2005, 25-26; Mählck ym. 2020; Nielsen 2016). Tällöin esimerkiksi rekrytoinnissa henkilöön tai identiteettiin liittyvät ominaisuudet, kuten sukupuoli, ikä tai tausta, nähdään joko epäolennaisina tekijöinä tai tekijöinä, jotka pitää tietoisesti häivyttää prosessista ulos. Tasa-arvonäkemys korostaa sukupuolten samankaltaisuutta, ja tuloksena on tasa-arvopolitiikka, jossa kaikkia kohdellaan samankaltaisesti (vrt. Ylöstalo 2012). Argumentti oli haastatteluissa yleinen, ja sillä perusteltiin erityisesti sitä, miksi positiivista erityiskohtelua tai naisille kohdennettuja toimia ei ollut hyödynnetty (esim. "rekrytoimme aina parhaan hakijan", "rekrytoinneissa mennään tiede edellä"). Korvajärven (2011) mukaan sukupuolineutraalius on suomalaisessa työelämässä yleinen sukupuolen tuottamisen tapa, joka piilottaa sukupuoleen liittyvät konfliktit. Sukupuolineutraalius ilmenee hiljaisuutena sukupuoleen liittyvissä asioissa, jolloin sukupuoli piilotetaan organisaatioista. Esimerkiksi rekrytointikriteerien mahdollisia liitäntöjä miehiä suosivaan normiin (Lund \& Tienari 2019; van den Brink \& Benschop 2011) ei tällöin kyseenalaisteta. Sukupuolineutraali tasa-arvokäsitys ei mahdollista naisille kohdennettuja tukitoimia tai positiivista erityiskohtelua, jotka nähtiin haastatteluissa sekä kulttuurisesti vieraina että vaikeina toteuttaa lainsäädännön vaatimusten näkökulmasta (mm. työntekijöiden tasapuolinen kohtelu) niissäkin tapauksissa, joissa ongelmia tunnistettiin.

Kolmas perustelu tasa-arvotoimien vähäisyydelle liittää yliopiston institutionaalisen tasa-arvotyön laajempaan politiikkakokonaisuuteen. Haastatteluissa tulivat vahvasti esiin yliopistojen paineet menestyä kansainvälisessä tutkimuskilpailussa. Tasa-arvotyötä verrattiin yliopistojen kansainvälistymistavoitteeseen, jota pidettiin 
ensisijaisena, kiireisiä toimia edellyttävänä (sukupuolineutraalina) tavoitteena. Tasa-arvotyö sai tällöin väistyä muiden, tärkeämpien tavoitteiden tieltä (vrt. Skjeie \& Teigen 2005). Tutkimushenkilöstön kansainväliseen rekrytointiin ei puolestaan haastattelujen perusteella liitetty intersektionaalista ulottuvuutta (ks. myös Pietilä ym. 2021).

Neljäs haastatteluissa esiin tullut perustelu tasa-arvopolitiikkojen vähäisyydelle liittyy yliopisto-organisaation piirteisiin ja käytettävissä oleviin resursseihin. Tieteenalojen erilaisuuden, yliopisto-organisaatioiden suuren koon ja hajautetun toimivallan katsottiin vaikeuttavan keskitettyjen politiikkojen muotoilua ja toimeenpanoa. Haluttomuus sääntelyyn oli yliopistoissa johtanut suosituksiin sitovien politiikkojen sijaan. Toisaalta henkilöstömääriltään pienissä yliopistoissa ei välttämättä koettu tarvetta virallisille tasa-arvolinjauksille tai tietyille ryhmille kohdennetuille toimille. Myös taloudelliset kannustimet ja resurssit vaikuttavat tasaarvotyön laajuuteen. Yliopistojen rahanjakomalli ei esimerkiksi kannusta yliopistoja kiinnittämään huomiota sukupuolten tasa-arvoon, eikä tasa-arvotoimien puutteista sanktioida (vrt. Corneliussen \& Seddighi 2020). Osa vastaajista toi esiin yliopistojen niukentuneet toimintaresurssit, joiden myötä hallinto kykenee selviytymään vain pakollisista tehtävistä. Yliopistojen tasa-arvotyöhön varatut resurssit tulivat esiin myös Nielsenin (2017) tutkimuksessa. Argumentti liittyy kolmanteen perusteluun, joka korostaa muiden kuin tasa-arvotavoitteiden kiireisyyttä, kun organisaatioissa kilvoitellaan rajallisista taloudellisista ja aikaresursseista.

Viides perustelu kuvastaa passiivisuutta tai jopa välinpitämättömyyttä tasa-arvotyötä kohtaan. Kyse on tällöin tasa-arvotyön hienovaraisesta vastustamisesta (Ylöstalo 2013), joka ilmenee siinä, että tasa-arvo-ongelmien toteaminen (esim. henkilöstön hyvin vinoutunut sukupuolijakauma) ei johtanut aktiivisiin toimenpiteisiin. Haastattelujen perusteella näyttää siltä, että vallitseva organisaatiokulttuuri ei kaikissa yliopistoissa kannustanut aktiiviseen tasa-arvotyöhön: aihe ei ollut näkyvästi esillä, eikä yliopiston johto ollut teemaan näkyvästi sitoutunut. Nielsenin (2017) mukaan ylimmän johdon sitoutuminen ja tuki ovat olennaisia tehokkaan tasa-arvotyön edistämisessä niin yliopistoissa kuin muissakin organisaatioissa (vrt. Kellough \& Naff 2004). Henkilöstön kiinnostuksessa tasa-arvotyötä kohtaan nähtiin olevan myös tieteenalakohtaisia eroja, mikä ilmeni koulutusten ja komiteoiden kokoonpanoissa. 


\section{Pohdinta}

Sukupuolten tasa-arvoa tutkijanuralla on edistetty Suomessa kansallisella tasolla tavoitteellisesti 1980-luvulta lähtien (Husu 2001, 85-87). Suomalaisissa yliopistoissa on tehty systemaattista tasa-arvotyötä jo pitkään. Esimerkkeinä tästä ovat tasaarvokomiteat ja niiden jo 1990-luvulta lähtien laatimat tasa-arvosuunnitelmat. Tutkimuksen perusteella voidaan todeta, että kaikki suomalaiset yliopistot ovat "tasa-arvon kannalla" ja ainakin retorisesti sitoutuneet edistämään sukupuolten tasa-arvoa tutkijanuralla. Kun tarkastellaan konkreettisia henkilöstöpoliittisia tasa-arvotoimia, yliopistojen tasa-arvotyö näyttäytyy kuitenkin jokseenkin varovaisena ja kunnianhimottomana (vrt. Tanhua 2020). Vastaavia piirteitä on Julkusen (2009, 112-113) mukaan nähtävissä kansallisessa tasa-arvopolitiikassa, jolla "tasaarvon edistäminen on edelleen pehmeää, tasa-arvotavoitteiden seurantaindikaattoreita asetetaan puutteellisesti ja vastuuta on siirtynyt määräaikaisille projekteille ruohonjuuritasolle". Holli ja kumppanit $(2005,148)$ toteavat, että Pohjoismaissa sitoudutaan laajasti tasa-arvotavoitteeseen. Kun tasa-arvoa ryhdytään tosiasiassa panemaan toimeen, retoriikan ja käytännön välille syntyy kuitenkin kuilu. Tämä näkyy myös suomalaisissa yliopistoissa.

Suurin osa suomalaisten yliopistojen hyödyntämistä tasa-arvotoimista edustaa konventionaalisia tasa-arvotyön organisatorisia puitteita, kuten tasa-arvo- ja yhdenvertaisuuskomiteat, koulutukset ja raportointijärjestelmät häirinnästä ilmoittamiseksi. On tosin huomattava, että analyysin ulkopuolelle jäi osa yliopistojen tasa-arvotoimista, kuten ohjeistukset rekrytointikomiteoiden kokoonpanosta sekä lakisääteiset palkkakartoitukset. Haastateltavat korostivat kaikkien tutkijoiden tasapuolista kohtelua, mikä heijastaa näkemystä tasa-arvosta naisten ja miesten yhtäläisinä oikeuksina (Ylöstalo 2012). Suomalaisissa yliopistoissa hyödynnetyt tasa-arvotoimet olivatkin sellaisia, että ne eivät kohdentuneet tietyn sukupuolen edustajiin. Radikaalimpia rakenteellisiin uudistuksiin tähtääviä interventioita ei juurikaan hyödynnetty. Esimerkiksi akateemiseen rekrytointiin, joka on tutkimuksen ja opetuksen uusiutumisen kannalta keskeinen prosessi, oli harvoin sisällytetty positiivista erityiskohtelua.

Tutkimuksessa hyödynnetty kategorisointi auttaa hahmottamaan, mitä tasaarvotoimia yliopisto-organisaatioiden toimijat pitivät mahdollisina toteuttaa. Suomalaisessa työelämässä vallalla ollut sukupuolineutraali tasa-arvokäsitys (Korva- 
järvi 2011; Ylöstalo 2012) kaventaa yliopistojen keinovalikoimaa edistettäessä naisten tutkijanuria. Voidaan kysyä, riittääkö nykyisenkaltainen institutionaalinen työ rakenteellisten tasa-arvo-ongelmien ratkaisemiseksi vai estääkö pyrkimys sukupuolineutraalisuuteen tasa-arvon toteutumisen (vrt. Ylöstalo 2012).

Institutionaalisen tasa-arvotyön ymmärretään yliopistoissa usein tapahtuvan tasa-arvo- ja yhdenvertaisuuskomiteoissa, joissa laaditaan lakisääteiset tasa-arvoja yhdenvertaisuussuunnitelmat. Vaikka kyseessä on tärkeä instituutio, vaarana voi olla, että tasa-arvon edistäminen jää erilliseksi politiikka-alueeksi, josta harva työ- ja opiskelijayhteisössä on välttämättä edes tietoinen, saati että moni kokisi tehtäväkseen edistää tasa-arvoa omalla toiminnallaan. Jos konkreettinen tasaarvotyö näyttäytyy pienen ryhmän toteuttamana, on vaarana, että tasa-arvotyö kutistuu organisaatiossa byrokraattiseksi välttämättömyydeksi (vrt. Ikävalko \& Kantola 2017).

Pohjoismainen vertailuasetelma osoitti, että suomalaiset yliopistot ovat hyödyntäneet aktiivisia tasa-arvotoimia keskimäärin selvästi vähemmän kuin ruotsalaiset ja norjalaiset yliopistot. Naisten osuuden kasvu neljännellä uraportaalla on siten todennäköisesti seurausta muista tekijöistä kuin yliopistojen tasa-arvopolitiikoista. Mikä sitten selittää yliopistojen aktiivisuuseroja eri maissa? Ensinnäkin naisten osuus suomalaisten yliopistojen neljännen uraportaan positioissa on pitkään ollut eurooppalaisittain vertailtuna varsin suuri, mikä on saattanut johtaa näkemykseen, että akuuttia tarvetta tasa-arvotoimille ei ole. Eniten eroa kuitenkin selittänevät maiden toisistaan poikkeavat yhteiskunnalliset tasa-arvoa koskevat perinteet ja diskurssit, jotka heijastuvat yliopistojen institutionaaliseen tasa-arvotyöhön. Kuten Nielsen $(2017,296)$ huomauttaa, sukupuolten tasa-arvo on säilynyt Ruotsissa ja Norjassa ajankohtaisena keskustelunaiheena. Suomessa sukupuolten tasa-arvolla on sen sijaan ollut marginaalisempi asema poliittisessa ja yhteiskunnallisessa keskustelussa. Aktiivisen tasa-arvotyön voikin tulkita sopivan yhteen ruotsalaisessa ja norjalaisessa yhteiskunnassa vallitsevien implisiittisten ja eksplisiittisten hyvää työnantajapolitiikkaa koskevien normien kanssa (vrt. March \& Olsen 1989).

Suomalaisten yliopistojen pohjoismaisia naapurimaita vähäisempi aktiivisuus sukupuolten tasa-arvon edistämisessä voi myös heijastaa heikompia kansallisia rakenteita, jotka eivät sisällä selkeitä vastuusuhteita tai kannustimia edistää tasaarvoa tavoitteellisesti ja pitkäjänteisesti korkeakoulu- ja tutkimussektorilla (vrt. Brunila 2009; Nielsen 2017). Tasa-arvoteemat eivät ole haastateltujen mukaan 
esimerkiksi keskeinen asia yliopistojen ja ministeriön välisissä tulosneuvotteluissa, eikä yliopistojen nykyinen rahanjakomalli sisällä komponentteja, jotka kannustaisivat tasoittamaan henkilöstön sukupuolirakennetta. Tilanne, jossa julkisista varoista riippuvaisten organisaatioiden perusrahoitusta on supistettu ja jossa tutkimus- ja koulutuspoliittista agendaa hallitsevat tehokkuus- ja kilpailukykypuhe sekä sukupuolineutraalit kansainvälistymistavoitteet, ei ylipäänsä ole suosiollinen sosiaalisten tavoitteiden, kuten sukupuolten tasa-arvon, edistämiselle.

Yliopistojen työnantaja-asema ja lisääntynyt autonomia henkilöstöasioissa ei näytä johtaneen vahvempaan tasa-arvopolitiikkaan, ainakaan käsillä olevilla mittareilla tarkasteltuna. Naisten tutkijanurien edistäminen ei näytä olleen keskeinen teema yliopistojen henkilöstöpoliittisissa strategioissa. Jotain yliopistojen tasaarvotyön vaikeudesta kertoo, että jo lähes 40 vuotta sitten esiin nostettuja määräaikaisten työsuhteiden jatkamiseen ja kutsuprofessuureihin liittyviä tasa-arvoongelmia ei ole vieläkään kaikilta osin ratkaistu.

\section{Kiitokset}

Tutkimus on toteutettu osana pohjoismaista NORDICORE-huippuyksikköä, jota on rahoittanut NordForsk (projektinumero 80713, ohjelma Gender in the Nordic Research and Innovation Area). NORDICORE:n osahankkeessa työskentelivät lisäkseni Charlotte Silander, Liza Reisel ja Ida Drange. Kaikki osahankkeessa mukana olleet osallistuivat kyselyn ja analyyttisen kategorisoinnin suunnitteluun. Kiitän tutkimukseen osallistuneita henkilöitä tutkimuksen mahdollistamisesta. Kiitän myös anonyymejä arvioitsijoita sekä tutkija Minna Leinosta käsikirjoituksen parannusehdotuksista.

\section{Kirjoittaja}

\section{Maria Pietilä}

VTT, tutkijatohtori, Itä-Suomen yliopisto

sähköposti: maria.pietila@uef.fi

twitter: @maria_pietila 


\section{Kirjallisuus}

Bain, 0. \& Cummings, W. (2000) Academe's glass ceiling: Societal, professional/ organizational, and institutional barriers to the career advancement of academic women. Comparative Education Review 44 (4), 493-514. https://doi.org/10.1086/447631

Bettio, F., Verashchagina, A., Mairhuber, I., Meulders, D., Beleva, I., Panayiotou, A., Křižkova, A. \& Emerek, R. (2009) Gender segregation in the labour market: Root causes, implications and policy responses in the EU. European Commission. Luxemburg: Publications Office of the European Union.

Borchorst, A., Freidenvall, L., Kantola, J., Reisel, L. \& Teigen, M. (2012) Institutionalizing intersectionality in the Nordic countries: Antidiscrimination and equality in Denmark, Finland, Norway, and Sweden. Teoksessa A. Krizsan, H. Skjeie \& J. Squires. (toim.) Institutionalizing intersectionality: The changing nature of European equality regimes. Lontoo: Palgrave Macmillan UK.

Brandt, E., Olsen, T. B. \& Vabø, A. (2002) Kjønn og forskning i Norge. NIFU skriftserie, nr 15/2002. Oslo: Norsk institutt for studier av forskning og utdanning.

Brunila, K. (2009) Sukupuolten tasa-arvo korkeakoulutuksessa ja tutkimuksessa. Sosiaali- ja terveysministeriön selvityksiä 2009:51. Helsinki.

Brunila, K. \& Ylöstalo, H. (2015) Challenging gender inequalities in education and in working life - a mission possible? Journal of Education and Work 28 (5), 443-460. https://doi.org/10.1080/13639080.2013.806788

Corneliussen, H. G. \& Seddighi, G. (2020) Employers' mixed signals to women in IT: Uncovering how gender equality ideals are challenged by organizational context. Teoksessa P. Kommers \& G. C. Peng (toim.) Proceedings for the International Conference ICT, Society, and Human Beings 2020. IADIS Press, 41-48.

Dobbin, F., Schrage, D. \& Kalev, A. (2015) Rage against the iron cage: The varied effects of bureaucratic personnel reforms on diversity. American Sociological Review 80 (5), 1014-1044. https://psycnet.apa.org/doi/10.1177/0003122415596416 
Euroopan komissio (2019) She figures 2018. DG for Research and Innovation. Bryssel: Euroopan komissio.

Fagenson, E. A. (1990) At the heart of women in management research: Theoretical and methodological approaches and their biases. Journal of Business Ethics 9, 267-274. https://doi.org/10.1007/BF00380326

HE 7/2009. Hallituksen esitys Eduskunnalle yliopistolaiksi ja siihen liittyviksi laeiksi. https://finlex.fi/fi/esitykset/he/2009/20090007

Holli, A. M. (2002) Suomalaisen tasa-arvopolitiikan haasteet. Teoksessa A. M. Holli, T. Saarikoski \& E. Sana (toim.) Tasa-arvopolitiikan haasteet. Helsinki: Tasa-arvoasiain neuvottelukunta, 12-30.

Holli, A. M., Magnusson, E. \& Rönnblom, M. (2005) Critical studies of Nordic discourses on gender and gender equality. NORA - Nordic Journal of Women's Studies 13 (3), 148-152. https://doi.org/10.1080/08038740600590442

Husu, L. (2001) Sexism, support and survival in academia: Academic women and hidden discrimination in Finland. Helsinki: Helsingin yliopisto, Sosiaalipsykologian laitos.

Ikävalko, E. \& Kantola, J. (2017) Feminist resistance and resistance to feminism in gender equality planning in Finland. European Journal of Women's Studies 24 (3), 233-248. https://doi.org/10.1177\%2F1350506817693868

Jauhiainen, A. (2011) Opetustyö ja sukupuoli uusliberalistisessa yliopistossa. Aikuiskasvatus 31 (3), 164-173.

Jordansson, B. (1999) Jämställdhetspolitikens villkor. Politiska intentioners möten med den akademiska världen: exemplet "Thamprofessurerna". Göteborg: Nationella sekretariatet för genusforskning.

Julkunen, R. (2009) Työelämän tasa-arvopolitiikka. Sosiaali- ja terveysministeriön selvityksiä 2009:53. Helsinki.

Kalev, A., Kelly, E. \& Dobbin, F. (2006) Best practices or best guesses? Assessing the efficacy of corporate affirmative action and diversity policies. American Sociological Review 71 (4), 589-617. https://doi.org/10.1177\%2F000312240607100404

Kanter, R. M. (1977) Men and women of the corporation. New York: Basic Books. Kantola, J. (2005) Mykät, kuurot ja kadotetut: sukupuolten välinen tasa-arvo Helsingin yliopiston valtio-opin laitoksella. Acta politica 29. Helsingin yliopisto, yleisen valtio-opin laitos. 
Kellough, J. E. \& Naff, K. C. (2004) Responding to a wake-up call: An examination of federal agency diversity management programs. Administration \& Society 36 (1), 62-90. https://psycnet.apa.org/doi/10.1177/0095399703257269

Korvajärvi, P. (2011) Practicing gender neutrality in organizations. Teoksessa E. L. Jeanes, D. Knights \& P. Y. Martin (toim.) Handbook of gender, work \& organization. Chichester: John Wiley, 231-243.

Lipinsky, A. (2013) Gender equality policies in public research: Based on a survey among members of the Helsinki group on gender in research and innovation. Report commissioned by the Directorate General for Research and Innovation of the European Commission.

Lund, R. \& Tienari, J. (2019) Passion, care, and eros in the gendered neoliberal university. Organization 26 (1), 98-121. https://doi.org/10.1177\%2F1350508418805283

March, J. G. \& Olsen, J. P. (1989) Rediscovering institutions. New York: Free Press.

Mählck, P., Kusterer, H. L. \& Montgomery, H. (2020) What professors do in peer review: Interrogating assessment practices in the recruitment of professors in Sweden. Gender, Work and Organization 27 (6), 1361-1377.

https://doi.org/10.1111/gwao.12500

Nielsen, M. W. (2014) Justifications of gender equality in academia: Comparing gender equality policies of six Scandinavian universities. NORA: Nordic Journal of Women's Studies 22 (3), 187-203.

https://doi.org/10.1080/08038740.2014.905490

Nielsen, M. W. (2016) Limits to meritocracy? Gender in academic recruitment and promotion processes. Science \& Public Policy 43 (3), 386-399.

https://doi.org/10.1093/scipol/scv052

Nielsen, M. W. (2017) Scandinavian approaches to gender equality in academia: A comparative study. Scandinavian Journal of Educational Research 61 (3), 295-318. https://doi.org/10.1080/00313831.2016.1147066

Niemi, J. (2009) Yliopistouudistuksen sukupuolivaikutukset? Kasvatus \& Aika $1(3), 63-69$.

Opetus- ja kulttuuriministeriö (2016) Neliportaisen tutkijanuramallin arviointihanke: Loppuraportti. 2016. Opetus- ja kulttuuriministeriön julkaisuja 2016:15. Helsinki. 
Opetusministeriö (1982) Naisten tutkijanuran ongelmat ja esteet: Opetusministeriön asettaman työryhmän mietintö. Helsinki.

Opetusministeriö (2006) Tutkijanuratyöryhmän loppuraportti. Opetusministeriön työryhmämuistioita ja selvityksiä 2006:13. Helsinki.

Parsons, E. \& Priola, V. (2013) Agents for change and changed agents: The micropolitics of change and feminism in the academy. Gender, Work \& Organization 20 (5), 580-598. https://doi.org/10.1111/j.1468-0432.2012.00605.x

Pietilä, M. (2018) Making Finnish universities complete organisations: Aims and tensions in establishing tenure track and research profiles. University of Helsinki, Department of Political and Economic Studies.

Pietilä, M. (2019) Incentivising academics: Experiences and expectations of the tenure track in Finland. Studies in Higher Education 44 (6), 932-945. https://doi.org/10.1080/03075079.2017.1405250

Pietilä, M., Drange, I., Silander, C. \& Vabø, A. (2021) Gender and globalization of academic labor markets: Research and teaching staff at Nordic universities. Social Inclusion 9 (3), 69-80. https://doi.org/10.17645/si.v9i3.4131

Powell, S., Ah-King, M. \& Hussénius, A. (2018) 'Are we to become a gender university?' Facets of resistance to a gender equality project. Gender, Work \& Organization 25 (2), 127-143. https://doi.org/10.1111/gwao.12204

Rinne, R., Jauhiainen, A., Simola, H., Lehto, R., Jauhiainen, A. \& Laiho, A. (2012) Valta, uusi yliopistopolitiikka ja yliopistotyö Suomessa: Managerialistinen hallintapolitiikka yliopistolaisten kokemana. Helsinki: Suomen kasvatustieteellinen seura.

Salmesvuori, P. (2020) Seksuaalinen häirintä vallankäyttönä. Esitys. Helsinki Association of Women Researchers.

Sivistystyönantajat (2020) Tilastojulkaisu 2019, yliopistot. Sivista.

Skjeie, H. \& Teigen, M. (2005) Political constructions of gender equality: Travelling towards a gender balanced society? NORA - Nordic Journal of Feminist and Gender Research 13 (3), 187-197. https://doi.org/10.1080/08038740600590004

Sosiaali- ja terveysministeriö (2020) Suomi tasa-arvon kärkimaaksi: Hallituksen tasa-arvo-ohjelma 2020-2023. Sosiaali- ja terveysministeriön julkaisuja 2020:35. Helsinki. 
Suomen Akatemia (1997) Naisten tutkijanuran edistäminen. Suomen Akatemian asettaman työryhmän muistio. Helsinki: Edita.

Tanhua, I. (2020) Selvitys korkeakoulujen tasa-arvon ja yhdenvertaisuuden edistämisestä. Opetus- ja kulttuuriministeriön julkaisuja 2020:20. Helsinki.

Tasa-arvoasiain neuvottelukunta (2011) Tasa-arvoasiain neuvottelukunnan toimintakertomus 2007-2011.

Teigen, M. (2011) Gender quotas on corporate boards. Teoksessa K. Niskanen (toim.) Gender and power in the Nordic countries - with focus on politics and business. Oslo: Nordic Gender Institute -NIKK, 87-110.

Timmers, T. M., Willemsen, T. M. \& Tijdens, K. G. (2010) Gender diversity policies in universities: A multi-perspective framework of policy measures. Higher Education 59 (6), 719-735. https://doi.org/10.1007/s10734-009-9276-z

Tuomi, J. \& Sarajärvi, A. (2002) Laadullinen tutkimus ja sisällönanalyysi. Helsinki: Tammi.

van den Brink, M. \& Benschop, Y. (2011) Gender practices in the construction of academic excellence: Sheep with five legs. Organization 19 (4), 507-524. https://doi.org/10.1177\%2F1350508411414293

Vipunen tietokanta (2021) Vipunen.fi. Opetushallinnon tilastopalvelu. https://vipunen.fi/fi-fi

VN (2017) Valtioneuvoston selonteko naisten ja miesten välisestä tasa-arvosta 2010: Väliraportti 2016. Sosiaali- ja terveysministeriön raportteja ja muistioita 2017:11. Helsinki.

Välimaa, J., Stenvall, J., Siekkinen, T., Pekkola, E., Kivistö, J., Kuoppala, K., Nokkala, T., Aittola, H. \& Ursin, J. (2016) Neliportaisen tutkijanuramallin arviointihanke: Loppuraportti. Opetus- ja kulttuuriministeriön julkaisuja 2016:15. Helsinki.

Ylöstalo, H. (2012) Tasa-arvotyön tasa-arvot. Acta Electronica Universitatis Tamperensis 1152. Tampereen yliopisto, Naistutkimus. http://urn.fi/urn:isbn:978-951-44-8656-2

Ylöstalo, H. (2013) Väärinymmärryksiä ja vastustamista: sukupuolinäkökulman valtavirtaistamisen käytännön ongelmia. Politiikka 55 (4), 223-238. 


\section{Maria Pietilä}

Finnish universities' gender equality measures in academic careers by Nordic comparison

Although women and men have completed doctoral degrees at Finnish universities in similar numbers for a long time already, women remain a minority in the highest academic positions, such as professorships. In this article, I analyse what institutional gender equality measures universities have taken to promote gender equality in academic careers. In addition to this, I analyse the challenges in promoting gender equality. I use an analytical categorisation that orders universities' equality policies into four classes. In the analysis, I compare the gender equality measures applied by Finnish universities from 2000 to 2018 with the measures applied by Swedish and Norwegian universities. The survey-based data have been collected through interviews at universities, the main respondents being representatives of human resource services. Based on the findings, Finnish universities have used fewer equality measures than those in Sweden and Norway. The most common equality measures at Finnish universities have been equality and diversity committees, grievance procedures, and equality and diversity training. The universities have hardly used more radical or politically controversial equality measures, such as preferential treatment in recruitment or measures targeted at women only. Based on the analysis, the gender-neutral approach to gender equality narrows Finnish universities' range of measures when promoting women's academic careers. 